\title{
Radiological follow-up of adults hospitalised with pneumonia and SARS-CoV-2 infection, in Bristol UK, during the COVID19 pandemic
}

Gabriella Ruffino ${ }^{1}$, Rachel L Williams ${ }^{2}$, Shaney Barratt ${ }^{3,5}$, Catherine Hyams ${ }^{1,3,4}$

${ }^{1}$ Acute Medical Unit, Southmead Hospital, Bristol, UK, BS10 5NB

${ }^{2}$ Research and Innovation, North Bristol NHS Trust, Southmead Hospital, Bristol, UK, BS10 $5 \mathrm{NB}$

${ }^{3}$ Academic Respiratory Unit, Learning and Research, Southmead Hospital, Bristol, UK, BS10 5NB

${ }^{4}$ Schools of Population Health Sciences and Cellular and Molecular Medicine, University of Bristol, UK, BS2 8AE

${ }^{5}$ Department of Respiratory Medicine, Southmead Hospital, Bristol, UK, BS10 5NB

Corresponding Author: Dr Catherine Hyams, MBBS BSc (Hons) PhD

Academic Respiratory Unit,

Learning and Research,

Southmead Hospital,

Bristol, UK, BS10 5NB

catherine.hyams@bristol.ac.uk

Running Title: Radiological follow up of pneumonia and SARS-CoV-2 infection

Keywords: $\quad$ Pneumonia, respiratory infection, COVID19, SARS-CoV-2, radiology

Funding: $\quad \mathrm{CH}$ was funded by the National Institute for Health Research [NIHR Academic Clinical Fellowship (ACF-2015-25-002). The views expressed are those of the author(s) and not necessarily those of the NIHR or the Department of Health and Social Care.

Declaration of Interests: $\mathrm{CH}$ is principal investigator of the Avon CAP study which is an investigator-led University of Bristol study funded by Pfizer and has previously received support from the NIHR in an academic clinical fellowship. The other authors have no relevant conflicts of interest to declare.

Word Count: $\quad 994 / 1000$ 
medRxiv preprint doi: https://doi.org/10.1101/2022.01.04.22268738; this version posted January 5, 2022. The copyright holder for this preprint

(which was not certified by peer review) is the author/funder, who has granted medRxiv a license to display the preprint in perpetuity.

All rights reserved. No reuse allowed without permission.

\section{ABSTRACT}

2 For patients with pneumonia and COVID19 repeating chest radiography is recommend in

3 current British Thoracic Society (BTS) guidelines. Over two distinct time periods during the

4 COVID19 pandemic (Aug-Dec 2020, Jun-Aug 2021) we undertook an audit of 829 patients

5 hospitalised with infective radiological change (pneumonia=481, COVID19=348). 654/829

6 patients (79\%) required radiological follow-up under BTS guideline criteria. 414/654 (63\%)

7 were planned, 322/654 (49\%) occurred and, of patients receiving radiological follow-up,

8 most occurred within BTS timelines (86\%). Further audits should be conducted to ensure

9 BTS guidelines adherence, to avoid delay in diagnosing underlying malignancy or chronic

10 lung disease.

11 
medRxiv preprint doi: https://doi.org/10.1101/2022.01.04.22268738; this version posted January 5, 2022. The copyright holder for this preprint (which was not certified by peer review) is the author/funder, who has granted medRxiv a license to display the preprint in perpetuity.

All rights reserved. No reuse allowed without permission.

\section{INTRODUCTION}

13 Obstructing lung lesions can cause pneumonia, and lung cancer remains a leading cause of

14 cancer-related death [1]. Therefore British Thoracic Society (BTS) guidelines recommend

15 repeating chest radiography following community-acquired pneumonia (CAP) diagnosis at 6-

16 weeks in patients 'at higher risk of underlying malignancy' [2].

18 The radiological changes following SARS-CoV-2 infection are similar to those occurring

19 with other coronaviruses, which can result in chronic lung changes on imaging and reduced

20 lung function $[3,4]$. Recent BTS guidelines recommend repeating radiology at 12-weeks post-

21 discharge for patients with a COVID19 diagnosis [5]. We therefore audited patients

22 hospitalised with lobar consolidation due to CAP and opacities consistent with COVID19

23 pneumonitis to determine current BTS guideline adherence.

\section{METHODS}

26 Adults $\geq 18$ years hospitalised to North Bristol NHS Trust were audited (1) from 1st August

27 until $30^{\text {th }}$ November 2020, and (2) $1^{\text {st }}$ June until $31^{\text {st }}$ July 2021. Patients were screened to

28 identify those admitted with signs/symptoms of acute respiratory disease. Only patients with

29 consolidation or opacities consistent with COVID19 pneumonitis on admission radiology

30 were included. Pneumonia was defined as new radiological shadowing with no alternate

31 explanation in the opinion of a consultant radiologist [2]. COVID19 radiological change was

32 defined as multiple bilateral peripheral opacities or other change in keeping with SARS-CoV-

332 infection [3].

35 Clinical data were collected from medical records. Patient eligibility for repeat radiology was

36 determined separately by two authors: if disagreement occurred then the case was discussed. 
medRxiv preprint doi: https://doi.org/10.1101/2022.01.04.22268738; this version posted January 5, 2022. The copyright holder for this preprint (which was not certified by peer review) is the author/funder, who has granted medRxiv a license to display the preprint in perpetuity.

All rights reserved. No reuse allowed without permission.

37 In both pneumonia and COVID19, patient follow-up was classified as under hospital team

38 (where radiology had to be booked) or GP (which required the discharge summary indicate

39 repeat radiology was required). Follow-up was assessed at 6- or 12-weeks for lobar

40 pneumonia and bilateral COVID19 pneumonitis respectively.

41

42 Categorical variables were presented as counts with percentages; continuous data as means 43 and standard deviations (SD) if normally distributed and medians and interquartile range

44 (IQR) if not normally distributed. Proportions were compared using Chi-squared testing; 45 comparison of medians using Mann-Whitney U-Test.

\section{RESULTS}

48 From Aug-Dec 2020, 308 adults were hospitalised with lobar pneumonia and 249 with

49 COVID19 pneumonitis. In June-Aug 2021, fewer adults were hospitalised with CAP (173) or

50 COVID19 pneumonitis (99) (Figure One). Patient demographics are listed in Table One.

51 COVID19 patients admitted from June-Aug 2021 were younger than those hospitalised in

52 Aug-Dec $2020(\mathrm{P}=0.036)$. In both time periods, a high proportion of patients were deemed

53 eligible for follow-up radiology (75\% CAP versus 81\% COVID19 Aug-Dec 20; and, 75\%

54 versus 93\% COVID19 Jun-Aug 21). However, in both audit periods fewer CAP patients had

55 radiology follow-up planned compared to COVID19 patients (54\% versus 69\%, and 62\%

56 versus $78 \%$ respectively) (Table Two). Of those with follow-up planned, most (80\%) had this

57 planned under the hospital team. 
Table 1: Characteristics of Patients Hospitalised with Radiologically Proven Respiratory Infection

\begin{tabular}{|c|c|c|c|c|c|c|}
\hline \multirow[t]{2}{*}{ Characteristic } & \multicolumn{3}{|c|}{ Cohort One (Aug-Dec 2020) } & \multicolumn{3}{|c|}{ Cohort Two (June-Aug 2021) } \\
\hline & $\begin{array}{l}\text { Pneumonia } \\
\mathbf{N}=\mathbf{3 0 8}\end{array}$ & $\begin{array}{c}\text { COVID19 } \\
\mathrm{N}=249\end{array}$ & $\begin{array}{c}\text { Total Cohort } \\
\text { N }=557\end{array}$ & $\begin{array}{c}\text { Pneumonia } \\
\mathrm{N}=173\end{array}$ & $\begin{array}{c}\text { COVID19 } \\
\mathrm{N}=99\end{array}$ & $\begin{array}{l}\text { Total Cohort } \\
\text { N =272 }\end{array}$ \\
\hline Age (years) - median (IQR) & $80.0(68.0-87.4)$ & $62.8(54.2-76.9)$ & $73.7(59.4-83.9)$ & $75.6(61.8-85.7)$ & $48.5(35.0-59.6)$ & $67.1(48.5-81.7)$ \\
\hline Male Gender - N $(\%)$ & $159(51.6)$ & $156(62.7)$ & $315(56.6)$ & $92(53 \cdot 2)$ & $62(62.6)$ & $154(56.6)$ \\
\hline Care home resident $-\mathrm{N}(\%)$ & $48(15.6)$ & $11(4.4)$ & $59(10.6)$ & $10(5 \cdot 8)$ & $0(0)$ & $10(3.7)$ \\
\hline \multicolumn{7}{|l|}{ Smoking - N (\%) } \\
\hline Current & $43(14.0)$ & $8(3.2)$ & $51(9.2)$ & $15(8 \cdot 7)$ & $5(5.1)$ & $20(7.4)$ \\
\hline Ex-smokers & $130(42.2)$ & $113(45.4)$ & $243(43.6)$ & $94(54.3)$ & $36(36.4)$ & $130(47.8)$ \\
\hline Unknown & $62(20.1)$ & $32(12.9)$ & $94(16.9)$ & $13(7.5)$ & $14(14.1)$ & $27(9.9)$ \\
\hline \multicolumn{7}{|l|}{ Comorbidity Scores - N (\%) } \\
\hline Rockwood Frailty 0-4 & $120(39.0 \%)$ & $203(81.5 \%)$ & $323(58.0 \%)$ & $103(59.5)$ & $89(89.9)$ & $192(70.5)$ \\
\hline Rockwood Frailty 5-9 & $188(61.0 \%)$ & $46(18.5 \%)$ & $234(42.0 \%)$ & $70(40 \cdot 5)$ & $10(10.1)$ & $80(29.4)$ \\
\hline CCI - median (IQR) & $5(4-7)$ & $3(1-4)$ & $4(2-6)$ & $4(2-6)$ & $1(0-3)$ & $3(1-5)$ \\
\hline \multicolumn{7}{|l|}{ Respiratory - N (\%) } \\
\hline Any & $140(54.5)$ & $68(27.3)$ & $208(37.3)$ & $81(46.8)$ & $28(28.3)$ & $109(40.1)$ \\
\hline COPD & $95(30.8)$ & $19(7.6)$ & $114(20.5)$ & $45(26.0)$ & $<5(<5.1)$ & $49(18.0)$ \\
\hline Asthma & $35(11.4)$ & $39(15.7)$ & $74(13.3)$ & $34(19.7)$ & $22(22.2)$ & $56(20.6)$ \\
\hline Other $*$ & $35(11.4)$ & $16(6.4)$ & $51(9.2)$ & $14(8.1)$ & $<5(<5.1)$ & $16(5.9)$ \\
\hline \multicolumn{7}{|l|}{ Cardiovascular - N (\%) } \\
\hline $\mathrm{CCF}$ & $54(17.5)$ & $16(6.4)$ & $70(12.6)$ & $21(12.1)$ & $<5(<5.1)$ & $24(8.8)$ \\
\hline Ischaemic Heart Disease & $62(20.1)$ & $32(12.9)$ & $94(16.9)$ & $24(13.9)$ & $<5(<5.1)$ & $28(10.3)$ \\
\hline \multicolumn{7}{|l|}{ Neurological - N (\%) } \\
\hline CVA/TIA & $39(12.7)$ & $18(7.2)$ & $57(10.2)$ & $21(12.1)$ & $0(0)$ & $21(7.7)$ \\
\hline Dementia & $40(13.0)$ & $7(2.8)$ & $47(8.4)$ & $12(6.9)$ & $0(0)$ & $12(4.4)$ \\
\hline Cognitive impairment & $21(6.8)$ & $7(2.8)$ & $28(5.0)$ & $11(6.4)$ & $0(0)$ & $11(4.0)$ \\
\hline Other chronic neurological condition $\ddagger$ & $20(6.5)$ & $10(4.0)$ & $30(5.4)$ & $7(4.0)$ & $<5(<5.1)$ & $8(2.9)$ \\
\hline \multicolumn{7}{|l|}{ Malignancy - N (\%) } \\
\hline None & $257(83.4)$ & $233(93.6)$ & $490(88.0)$ & $151(87.3)$ & $93(93.9)$ & $244(89.7)$ \\
\hline Solid Organ Cancer & $42(13.6)$ & $10(4.0)$ & $52(9.4)$ & $21(12.4)$ & $5(5.1)$ & $26(9.6)$ \\
\hline Haematological Malignancy & $12(3.6)$ & $7(2.9)$ & $19(3.5)$ & $<5(<2.8)$ & $<5(<5.1)$ & $<5(<1.8)$ \\
\hline
\end{tabular}

* Includes bronchiectasis, pulmonary fibrosis, and other chronic respiratory conditions

$5 \quad$ "Includes Parkinson’s disease, Huntingdon’s disease, and other chronic neurological conditions not including CVA, TIA, Dementia or Cognitive Impairment

$6 \mathrm{CCF}$, congestive cardiac failure; CVA, cerebrovascular accident; COPD, chronic obstructive pulmonary disease; IQR, interquartile range; TIA, Transient Ischaemic Attack 
medRxiv preprint doi: https://doi.org/10.1101/2022.01.04.22268738; this version posted January 5, 2022. The copyright holder for this preprint

(which was not certified by peer review) is the author/funder, who has granted medRxiv a license to display the preprint in perpetuity.

All rights reserved. No reuse allowed without permission.

1 Repeat radiological examination occurred in $49 \%$ eligible patients, and $42 \%$ underwent

2 investigation within BTS guideline timeframe (Table Two). 30\% COVID19 patients admitted

3 in June-Aug 2021 received follow-up per guidelines when arranged under the hospital team;

4 in all other patient groups approximately $80 \%$ patients with hospital follow-up arranged

5 underwent such follow-up. Patients with GP led follow-up tended to be less likely to receive

6 follow-up within guideline criteria $(\mathrm{P}=0.003)$; although, there are small numbers in this audit. 
1 Table 2: Radiological follow-up of patients with pneumonia and COVID19

2

\begin{tabular}{|c|c|c|c|c|c|c|}
\hline \multirow[t]{2}{*}{ Radiological Follow-Up } & \multicolumn{3}{|c|}{ Cohort One (Aug-Dec 2020) } & \multicolumn{3}{|c|}{ Cohort Two (June-Aug 2021) } \\
\hline & $\begin{array}{c}\text { Pneumonia } \\
\mathbf{N}=\mathbf{3 0 8}\end{array}$ & $\begin{array}{c}\text { COVID19 } \\
\mathrm{N}=249\end{array}$ & $P$-value & $\begin{array}{c}\text { Pneumonia } \\
\quad \mathrm{N}=173\end{array}$ & $\begin{array}{c}\text { COVID19 } \\
N=99\end{array}$ & $P$-value \\
\hline \multicolumn{7}{|c|}{ Patients Eligible under BTS Guidelines ${ }^{\dagger}$ - N (\%) } \\
\hline Not eligible & $77 / 308(25)$ & $48 / 249(20)$ & - & $43 / 173(25)$ & $7 / 99(7)$ & \\
\hline Eligible for follow-up & $231 / 308(75)$ & $201 / 249(81)$ & - & $130 / 173(75)$ & 92/99 (93) & \\
\hline \multicolumn{7}{|l|}{ Plan on Discharge - N (\%) } \\
\hline No follow-up booked & $106 / 231(46)$ & $63 / 201(31)$ & 0.0001 & $49 / 130(38)$ & $20 / 92(22)$ & 0.0116 \\
\hline Self-discharge before follow-up booked & $1 / 231(0)$ & $0 / 201(0)$ & NS & $1 / 130(1)$ & $0 / 92(0)$ & NS \\
\hline Radiology plan implemented & $124 / 231(54)$ & $138 / 201(69)$ & 0.0015 & $80 / 130(62)$ & $72 / 92(78)$ & 0.0076 \\
\hline - Under hospital team & $72 / 124(58)$ & $113 / 138(82)$ & $<0.0001$ & $62 / 80(78)$ & $67 / 72(93)$ & 0.0097 \\
\hline - Under GP & $43 / 124(35)$ & 20/138 (14) & 0.0002 & $11 / 80(14)$ & $5 / 72(7)$ & NS \\
\hline - Documented plan not to repeat radiology & $9 / 124(8)$ & $5 / 138(4)$ & NS & $7 / 80(9)$ & $0 / 72(0)$ & NS \\
\hline \multicolumn{7}{|l|}{ Follow-up Occurrence - N (\%) } \\
\hline Total patients undergoing repeat radiology & $97 / 235(41)$ & $118 / 201(59)$ & 0.0004 & $64 / 130(49)$ & $43 / 92(47)$ & NS \\
\hline Follow-up occurred within timeframe & $87 / 235(37)$ & $104 / 201(52)$ & 0.0017 & $60 / 130(46)$ & $25 / 92(27)$ & 0.0042 \\
\hline - Under hospital team & $58 / 72(81)$ & $93 / 113(82)$ & NS & $51 / 62(82)$ & $20 / 67(30)$ & $<0.0001$ \\
\hline - Under GP & $29 / 43(67)$ & $11 / 20(55)$ & NS & $9 / 11(82)$ & $5 / 5(100)$ & NS \\
\hline
\end{tabular}

${ }^{\dagger}$ Patient eligibility for repeat chest radiograph under BTS guidelines[2,5] was determined separately by two authors, and where there was disagreement a discussion to determine eligibility occurred.

7 GP, General Practitioner; NS, not-significant 
medRxiv preprint doi: https://doi.org/10.1101/2022.01.04.22268738; this version posted January 5, 2022. The copyright holder for this preprint (which was not certified by peer review) is the author/funder, who has granted medRxiv a license to display the preprint in perpetuity.

All rights reserved. No reuse allowed without permission.

\section{DISCUSSION}

2 Appropriate patient follow-up is important to detect early and potentially treatable respiratory disease.

$32.5 \%$ of chest radiographs repeated $<90$ days of pneumonia diagnosis result in lung cancer diagnosis,

4 with cancer diagnostics predicted to increase if radiographs were only repeated in patients $>50$ years [6].

5 COVID19 prompted new BTS guidelines advising repeated radiological investigation 12-weeks post-

6 discharge to facilitate early diagnosis of chronic lung changes.

In this single-centre audit, fewer CAP patients eligible for radiological follow-up had documented plans

9 before hospital discharge when compared to COVID19 patients. We found some changes in guideline adherence across the two audit periods, with planned follow-up for both COVID19 pneumonitis and CAP increasing between the audit periods. However, the proportion of COVID19 patients undergoing radiological follow-up decreased (59\% versus $47 \%, \mathrm{P}=0.04$ ), whereas CAP follow-up slightly increased (41\% versus $49 \%, \mathrm{P}=0.14$ ). Additionally, follow-up within timeframe increased in CAP patients but reduced in COVID19 patients. The time-period for COVID19 follow-up is longer than that for CAP, and therefore it is possible pressure on healthcare had more effect on COVID19 follow-up.

These changes in guideline adherence observed have no notable trend and it would be inappropriate to conclude definitive reasons for any changes. BTS CAP guidelines [2] are well established and 86\% radiological follow-up occurring did so in timeframe, with minimal change between the two audit periods. This suggests guideline familiarity is not contributing to adherence. However, only $63 \%$ eligible patients had follow-up planned and there is clearly need for improvement, as this leaves a significant number of patients without appropriate follow-up to detect either lung malignancy or chronic lung disease early. Further to this, $18 \%$ of planned follow-up did not take place and this needs to be addressed. 
medRxiv preprint doi: https://doi.org/10.1101/2022.01.04.22268738; this version posted January 5, 2022. The copyright holder for this preprint (which was not certified by peer review) is the author/funder, who has granted medRxiv a license to display the preprint in perpetuity.

All rights reserved. No reuse allowed without permission.

25 There is sparse literature concerning radiology follow-up following pneumonia. An audit from 2015 suggested $43 \%$ patients $\geq 50$ years had appropriate advice given regarding radiology follow-up, with $15 \%$

27 undergoing repeat imaging [7]. A previous local audit showed 51\% (55/107) patients underwent 28 radiological follow-up within 6-weeks of presentation [8]. This audit aligns with previous literature, 29 suggesting $49 \%$ planned follow-up occurred: $42 \%$ within BTS timelines.

31 This audit has many strengths. Firstly, it was conducted at a University hospital with specialist 32 respiratory services and recruited many patients with CAP and COVID19. We repeated the audit over two time periods, to determine if there was any change in BTS guideline adherence. There are some

34 limitations, and this is a single-centre audit so results may not be generalisable. By necessity we audited 35 time periods when the NHS was under considerable pressure, and therefore rates of appropriate followup may improve when services are not under such strain.

These data suggest BTS guideline adherence regarding radiological follow-up may be suboptimal, with room for improvement and consequently improved patient outcomes. This audit should be undertaken at additional hospitals, and potentially nationally, to ensure appropriate BTS guidelines adherence thereby avoiding delay in diagnosing underlying malignancy or chronic lung disease. 
medRxiv preprint doi: https://doi.org/10.1101/2022.01.04.22268738; this version posted January 5, 2022. The copyright holder for this preprint (which was not certified by peer review) is the author/funder, who has granted medRxiv a license to display the preprint in perpetuity.

All rights reserved. No reuse allowed without permission.

43

44

45

46

47

48

49

50

51

52

53

54

55

56

57

58

59

60

61

62

63

64

\section{REFERENCES}

1 Valvani A, Martin A, Devarajan A, et al. Postobstructive pneumonia in lung cancer. Ann Transl Med 2019;7:357. doi:10.21037/atm.2019.05.26

2 Lim WS, Baudouin SV, George RC, et al. BTS guidelines for the management of community acquired pneumonia in adults: update 2009. Thorax 2009;64 Suppl 3:iii1-55. doi:10.1136/thx.2009.121434

3 George PM, Barratt SL, Condliffe R, et al. Respiratory follow-up of patients with COVID-19 pneumonia. Thorax 2020;75:1009-16. doi:10.1136/thoraxjnl-2020-215314

4 Rai DK, Sharma P, Kumar R. Post covid 19 pulmonary fibrosis. Is it real threat? Indian J Tuberc 2021;68:330-3. doi:10.1016/j.ijtb.2020.11.003

5 British Thoracic Society guidance on respiratory follow up of patients with a clinico-radiological diagnosis of COVID-19 pneumonia. 2020.https://www.brit-thoracic.org.uk/covid-19/covid-19information-for-the-respiratory-community/ (accessed 11 Dec 2021).

6 Tang KL, Eurich DT, Minhas-Sandhu JK, et al. Incidence, correlates, and chest radiographic yield of new lung cancer diagnosis in 3398 patients with pneumonia. Arch Intern Med 2011;171:1193-8. doi:10.1001/archinternmed.2011.155

7 Chisholm C, Rai R, Kaushal N. Audit to assess the follow-up of community acquired pneumonia with chest radiographs. Clin Radiol 2016;71:S13. doi:10.1016/j.crad.2016.06.071

8 Burt H, Chandratreya L. Are follow-up chest x-rays being performed according to British Thoracic Society Guidelines on adults diagnosed radiologically with Community Acquired Pneumonia? https://www.eposters.net/poster/are-follow-up-chest-X-rays-being-performed-according-to-britishthoracic-society-guidelines-on (accessed 11 Dec 2021). 
medRxiv preprint doi: https://doi.org/10.1101/2022.01.04.22268738; this version posted January 5, 2022. The copyright holder for this preprint (which was not certified by peer review) is the author/funder, who has granted medRxiv a license to display the preprint in perpetuity.

All rights reserved. No reuse allowed without permission.

\section{AUTHOR CONTRIBUTIONS}

$66 \mathrm{CH}, \mathrm{SB}$ and GR generated the research questions. GR and $\mathrm{CH}$ undertook data collection and act as data 67 verifiers. $\mathrm{CH}, \mathrm{GR}, \mathrm{RW}$ and $\mathrm{SB}$ contributed to the data analysis and prepared the manuscript for 68 publication.

69

70

\section{ACKNOWLEDGEMENTS}

71 We would like to acknowledge the support of the IT team at North Bristol NHS Trust in undertaking this 72 audit.

73

\section{DATA SHARING}

75 No additional data available.

76

77

78

79 
medRxiv preprint doi: https://doi.org/10.1101/2022.01.04.22268738; this version posted January 5, 2022. The copyright holder for this preprint (which was not certified by peer review) is the author/funder, who has granted medRxiv a license to display the preprint in perpetuity.

All rights reserved. No reuse allowed without permission.

\section{FIGURE LEGENDS}

81

\section{Figure One: Study Flow Diagram}

$83 \mathrm{n}$ this audit of adults hospitalised at Southmead hospital, there were (A) 557 adults in Aug-Dec 2020 and

84 (B) 272 adults in Jun-July 2021 with confirmed lobar pneumonia or pneumonitis on their initial chest

85 radiology.

86 aLRTD, acute lower respiratory tract disease; HAP, hospital acquired pneumonia 
2,973 adults hospitalised

1,270 patients with signs/ symptoms of possible aLRTD
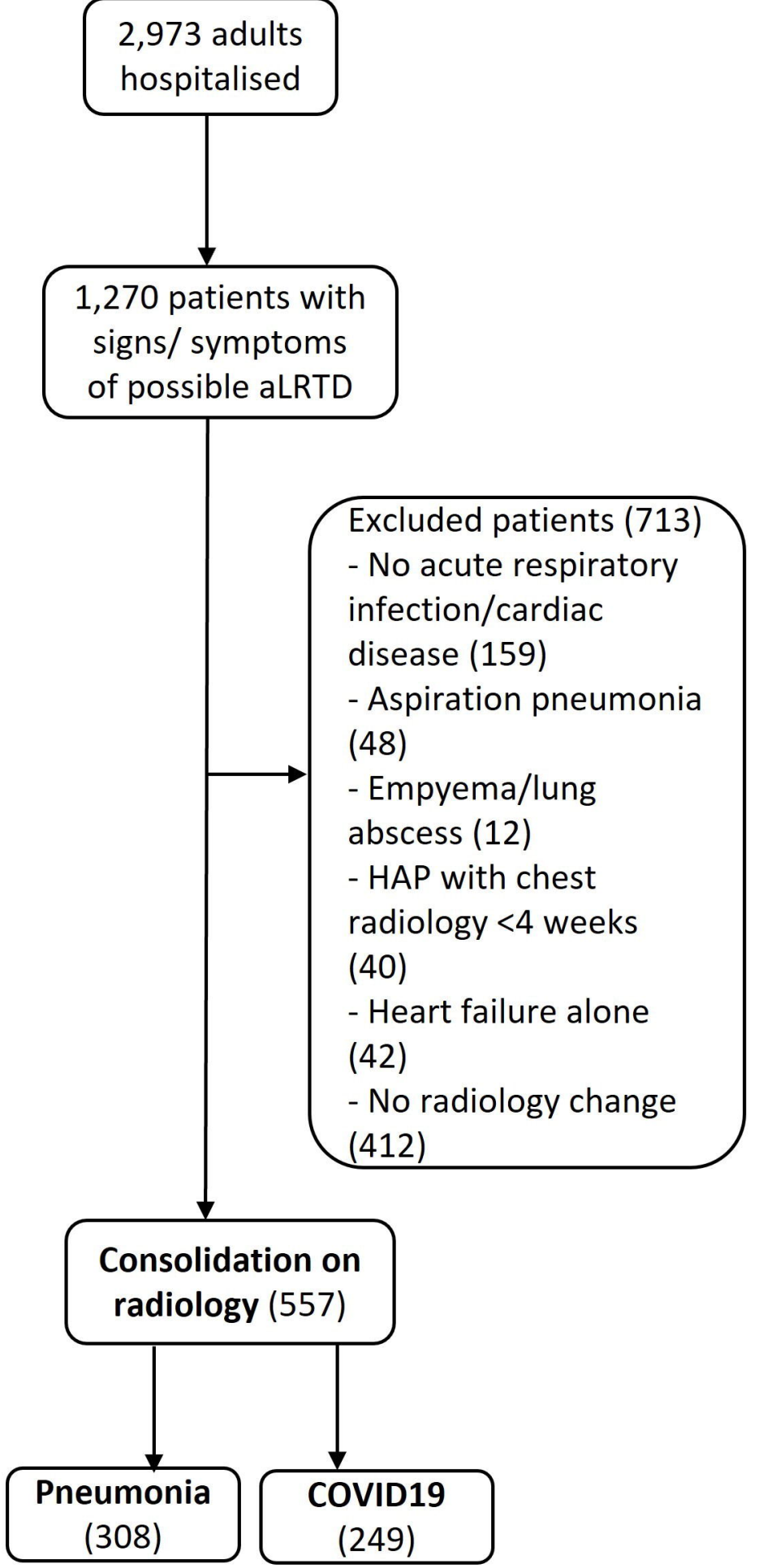

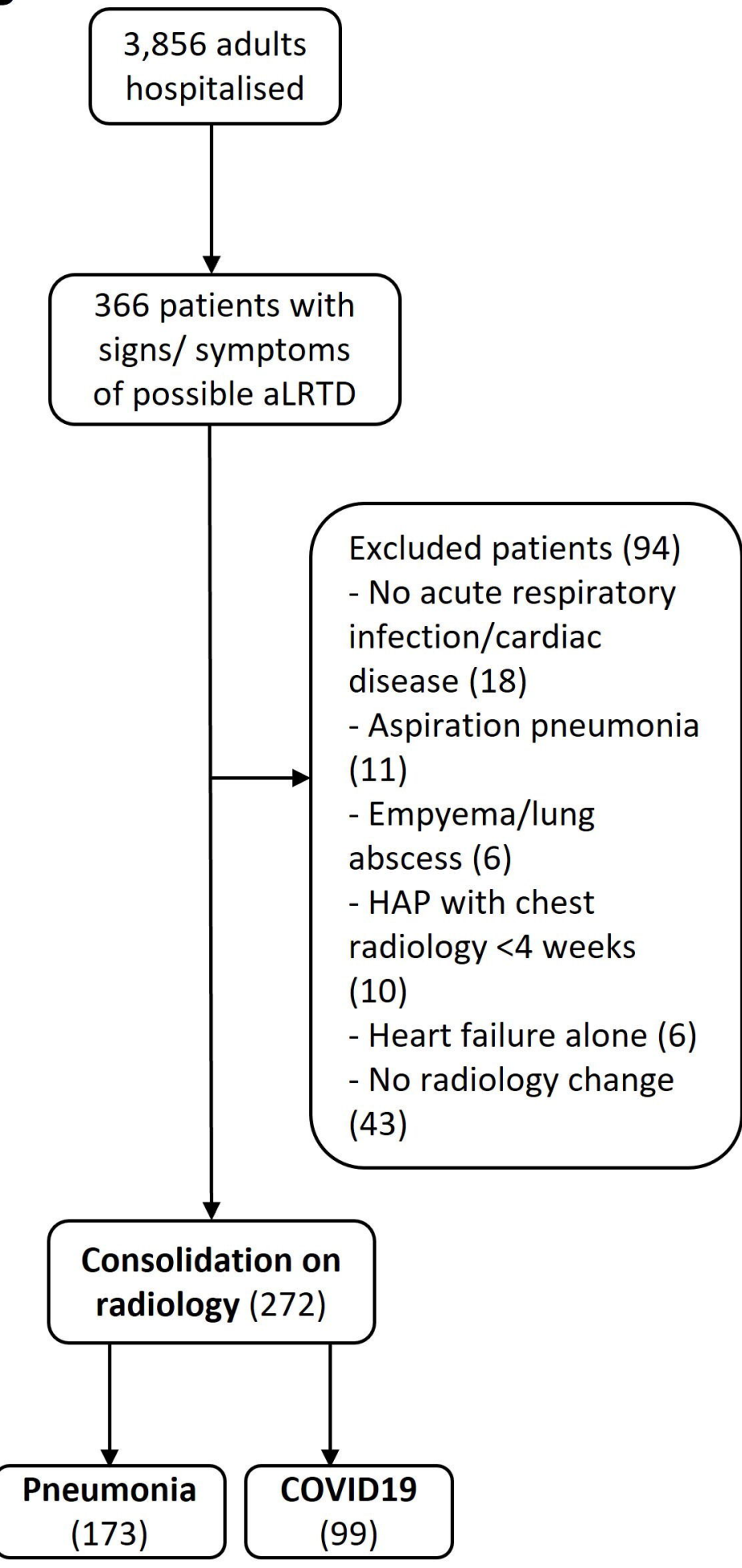

